The Corpse and the Conqueror: The Curious Afterlife of Ívarr inn beinlausi Kristen Mills, University of Oslo

Set during the Viking Age, Ragnars saga loðbrókar ok sona hans relates the exploits of the legendary warrior and king Ragnarr loðbrók 'hairy breeches' and his sons. While it is debated to what extent the figure celebrated in Old Norse and Scandinavian Latin medieval texts corresponds to a historical figure or figures mentioned in Viking Age sources, it would be difficult to overstate Ragnarr's importance for medieval Icelandic and Danish conceptualizations of a glorious past. ${ }^{1}$ The fullest version of Ragnars saga is the Y redaction, which is extant in a single medieval Icelandic manuscript, ${ }^{2}$ Ny kgl. saml. 1824b 4to, now held in The Royal Library in Copenhagen. The manuscript is dated to c. 1400, but this version of the saga was probably composed in the late thirteenth century. ${ }^{3}$ In addition to Ragnars saga, Ny kgl. saml. 1824b 4to contains two other texts: the only extant medieval version of Volsunga saga, and an incomplete version of Krákumál, a poem attributed to Ragnarr as he lay dying. In this version of the saga Ragnarr's second wife is Áslaug, the daughter of the famed dragon-slayer Sigurðr and the valkyrie Brynhildr, whose doomed love affair is recounted in Volsunga saga; it is has been suggested that Volsunga saga may have composed as a 'preamble' to Ragnars saga. ${ }^{4}$ Áslaug

I am indebted to Richard Cole, Thomas D. Hill, Joseph Nagy, and the Editor and peer-reviewers of $J E G P$ for their valuable comments and suggestions. All errors are my own.

${ }^{1}$ For the most recent treatment of the development of the legend of Ragnarr loðbrók, see Elizabeth Ashman Rowe, Vikings in the West: The Legend of Ragnarr Loðbrók and His Sons (Vienna: Fassbaender, 2012), especially 13-55 (contemporary sources), 96-106 (Danish sources), and 191-223 (thirteenth-century Icelandic sources).

${ }^{2}$ While this is the only medieval copy of this redaction of Ragnars saga, there are numerous post-medieval paper copies of the texts found in Ny kgl. saml. 1824b 4to.

${ }^{3}$ Rowe, Vikings in the West, 207. Ragnars saga is usually categorized as a fornaldarsaga, but it shares features with the genre of konungasögur, particularly in its use of skaldic verse, and Rowe suggests that "a major motivation for composing the saga was to provide a "legendary history" for the descendants of the settlement-era chieftain Höfða-Pórðr, who is said in the saga to be a descendant of Bjǫrn járnsiða. Rowe, Vikings in the West, 208.

${ }^{4}$ Torfi H. Tulinius, 'The Matter of the North: Fiction and Uncertain Identities in Thirteenthcentury Iceland', in Old Icelandic Literature and Society, ed. Margaret Clunies Ross (Cambridge: Cambridge University Press, 2000), 242-65, at 249. See also Bjarni Guðnason, 'Gerðir og ritpróun Ragnars sögu loðbrókar', in Einarsbók: Afmceliskveðja til Einars Ól. Sveinssonar, 12. desember 1969, eds. Bjarni Guðnason, Halldór Halldórsson and Jónas Kristjánsson (Reykjavík:Nokkrir vinir, 1969), 28-37; Rory McTurk, 'The Extant Icelandic Manifestations of Ragnars saga Loðbrókar’, Gripla 1 (1975), 43-75. 
bears five sons to Ragnarr: Ívarr inn beinlausi ‘the boneless’, Bjǫrn járnsíða ‘ironside’, Hvítserkr, Rǫgnvaldr, and Sigurðr ormr-í-auga 'snake-in-the-eye'. Áslaug advises Ragnarr to wait three nights after their wedding before consummating the marriage, predicting that if they do not abstain, the resulting child will lack bones; Ragnarr will not wait, and Ívarr is born, as prophesied, boneless. Ragnarr is later killed in a dramatic fashion by Ælla, king of Northumbria, prompting Ragnarr's sons to sail to England in order to avenge their father. After killing Ælla, the younger sons divide Scandinavia amongst themselves, while Ívarr remains in England to rule. This version of Ragnars saga gives an intriguing account of Ívarr's death, burial, and later exhumation. The account is as follows:

En Ívarr réð fyrir Englandi allt til dauðadags ok varð sóttdauðr. Ok pá er hann lá í banasótt, mælti hann, at hann skyldi pangat færa, er herskátt væri, ok pess kvaðst hann vænta, at peir mundi eigi sigr fá, er par kæmi at landinu. Ok er hann andast, var svá gert sem hann mælti fyrir, ok var pá í haug lagiðr. Ok pat segja margir menn, pá er Haraldr konungr Sigurðarson kom til Englands, at hann kæmi par at, er Ívarr var fyrir, ok fellr hann í peiri för. Ok er Vilhjálmr bastarðr kom í land, fór hann til ok braut haug Ívars ok sá Ívar ófúinn. Pá lét hann gera bál mikit ok lætr Ívar brenna á bálinu, ok eftir pat berst hann til landsins ok fær gagn. ${ }^{5}$

(Ívarr ruled over England until his dying day, and he died from illness. And when he lay on his deathbed, he said that he should be brought thence to where the land would be exposed to raids, and he said that he expected that those who came to land there would not have victory. And when he died, it was done as he had said before, and he was laid in a burial mound. And many men say that when king Haraldr Sigurðarson came to England that he landed there, where Ívarr was, and he died on that journey. And when William the Bastard invaded, he went there and broke into Ívarr's burial mound, and saw that Ívarr was undecayed. Then he had a great pyre kindled and had Ívarr burned on the pyre, and after that he invaded the land and gained the advantage.)

In some respects, this is a typical account of an encounter with the undead in medieval Icelandic literature. Known by various terms, including draugr, aptrganga ('after walker'), and haugbúi

\footnotetext{
${ }^{5}$ Guðni Jónsson, ed., Ragnars saga loðbrókar ok sona hans, in Fornaldarsögur norðurlanda 1 (Reykjavík: Íslendingasagnaútgáfan, 1943), ch. 28, 280. Translations are my own unless otherwise noted.
} 
('mound-dweller'), the undead appear frequently in the sagas. Some emerge from the grave in order to torment the living; others only interact with those who are brave (or foolish) enough to engage in haug-brot, the act of breaking into a grave-mound or cairn (E461.2: 'Fight of living person with dead in the grave'; E461.1: 'Fight of revenant with living person'). ${ }^{6}$ Haug-brot occurs in a number of fornaldarsögur and Íslendingasögur, and the act is often carried out with the intention of stealing weapons or treasure from the dead, who often enact an aggressive resistance against the living intruders. Nor was grave-robbing confined to the imagination, as the practice is amply attested in the archaeological record for the Viking Age. ${ }^{7}$ Drawing on both textual and archaeological evidence, Alison Klevnäs has analysed the ways in which the removal of personal objects and the removal or destruction of corpses from burial mounds may be linked to the transferral of power between regimes. She observes that '( $\mathrm{g})$ rave disturbance' is 'disruptive in very specific ways. The reopeners do not raze monuments, which are invariably left in place, but rather rework the associations invoked by them. The disturbed graves are left standing as testimonies to their breaking: everything is in place except the crucial core, the body and its closest possessions. An absence is created within the monuments, which is as much more powerful statement than razing and obliterating., 8

While lack of corruption in a corpse is usually an indication of sainthood in medieval sources, it can also have less wholesome connotations. Icelandic draugar often do not rot per se, but swelling and discoloration are typical. Fire is one of the preferred methods for dealing with revenants during the Middle Ages, in Nordic regions and elsewhere, ${ }^{9}$ and the burning of a corpse in order to prevent it from rising from the grave, or to break its protection or power after death, is a common motif in medieval Icelandic literature (E431.13: "Corpse burned to prevent return,"

\footnotetext{
${ }^{6}$ Boberg, Motif-Index.

${ }^{7}$ Bjørn Myhre, 'Haugbrott eller gravplyndring I tidlig kristningstid?', in Fra Hammer til Kors: 1000 Ar med kristendom, Brytningstid $i$ Viken, eds. Jan Ingar Hansen and Knut G. Bjerva (Oslo: Schibsted, 1994), 68-86.

${ }^{8}$ Alison Margaret Klevnäs, "Imbued with the Essence of the Owner": Personhood and Possessions in the Reopening and Reworking of Viking Age Burials,' European Journal of Archaeology 19 (2015): 456-476, at 466.

9 John Blair, 'The Dangerous Dead in Early Medieval England', in Early Medieval Studies in Memory of Patrick Wormald, eds. Stephen Baxter, Catherine Karkov, Janet L. Nelson, and David Pelteret (Farnham, Surrey: Ashgate, 2009), 539-59: 550. Nancy Caciola, 'Wraiths, Revenants, and Ritual in Medieval Culture', Past and Present 152 (1996), 3-45: 21-2.
} 
E446.2: "Ghost laid by burning body"). ${ }^{10}$ Eyrbyggja saga recounts the burning of Pórólfr bægifót's restless corpse and the scattering of his ashes, though the method is not wholly successful, as a cow licks some of the ashes and gives birth to a monstrous calf. ${ }^{11}$ Though this is not always the case, it is frequently those who were especially unpleasant or greedy while alive who are restless in death. In Laxdoela saga, Víga-Hrappr 'killer Hrappr' arranges it with his wife that he will be buried upright under the doorframe of his home, guarding it after death. VígaHrappr proves to be even less popular in death than in life, and his frequent nocturnal excursions, during which he terrorizes and occasionally kills the living, result in his exhumation and burial in a more remote location. This is effective for a time, but Víga-Hrappr eventually returns to menace his old home and its new inhabitants. This time his exhumed corpse is burned, and the ashes scattered. ${ }^{12}$ Consider also the example of Snjófríor, wife of Haraldr hárfagri: her seemingly uncorrupt corpse retains the colour of a living woman, and thereby entrances her husband to sit by her side for three years. Finally an adviser persuades the king that the queen's bedclothes should be changed, and when the corpse is moved it is revealed to be infested with all manner of creeping things. Her body is burnt on a pyre, and the king resumes ruling his kingdom. ${ }^{13}$ While Ívarr's lack of corruption would have been an immediately recognizable trope for contemporary Icelandic audiences, what the author of Ragnars saga intended to be inferred from the state of his corpse is ambiguous. Is Ívarr's preservation caused by demonic influence or pernicious sorcery, is it a sign of extraordinary virtue, or something else?

Two stories told about the relics of Óláfr Haraldsson may be useful here. According to the account in Heimskringla, Óláfr's relics are disinterred a year a five days after his death, to check if they have undergone corruption. His cheeks are ruddy, and his hair and nails have continued to grow. Álfífa, mother of King Sveinn, is unimpressed by this evidence of saintliness,

\footnotetext{
${ }^{10}$ Inger Margrethe Boberg, Motif-Index of Early Icelandic Literature, Bibliotheca Arnamagaeana 27 (Copenhagen: Munksgaard, 1966).

${ }^{11}$ Einar Ó1 Sveinsson and Matthías Pórðarson,eds., Eyrbyggja saga, Íslenzk fornrit, 4 (Reykjavík: Hið íslenzka fornritafélag, 1935), 93-5, 169-76.

${ }^{12}$ Einar Ól Sveinsson, ed., Laxdoela saga, Íslenzk fornrit, 5 (Reykjavík: Hið íslenzka fornritafélag, 1934), pp. 39-40, 69.

${ }^{13}$ Bjarni, Heimskringla I, 127.
} 
and scoffs that the corpse is uncorrupted because it was resting in sand, not soil. ${ }^{14}$ She declares that she will concede the holiness of the relics if a lock of Óláfr's hair does no burn. Bishop Grímkell blesses a fire in a firepan and adds incense, then places the hair in the fire. After all of the incense has been burned to ash, the hair remains, and though Álfífa remains unconvinced, the bishop, the king, and those assembled concur that Óláfr is a saint. The Manx Chronicle relates that Óláfr's rest was disturbed again in 1098, resulting in Magnús berfoettr's expeditions to Britain and Ireland. Magnús ordered the resting place of the saint to be opened, in order to test whether the his body had succumbed to decay. Magnús saw and felt the uncorrupted flesh before fleeing in terror. Óláfr appeared to him in a dream that night, offering him a choice: he can stay in Norway and lose his kingdom and his life within the month, or go into exile, never to return. Magnus takes 160 ships and sails to Orkney. ${ }^{15}$ The author of Ragnars saga may well have been familiar with the account in Heimskringla, and it is possible, though less likely, that he could have known the tradition recorded in the Manx Chronicle. Nothing in these accounts is exceptional in terms of medieval canonization narratives, but they do throw into relief a tension between the holy and the horrific in the description of Ívarr's exhumation in Ragnars saga. After death, Óláfr, saint and former king, remains a powerful figure- - his body does not decay, he cannot be burned, he manifests in dreams, and he can cause a man's death. By contrast, Ívarr's body remains uncorrupted for nearly two centuries, assuming that the saga's chronology corresponds roughly to the date of the historical Ívarr's death in the late ninth century, but his body succumbs to the flames in the end. His power is wholly seated in his flesh. Ívarr occupies an uncanny position between saint and draugr.

There are, however, aspects of this account that differ markedly from what one would usually find in Old Norse or Scandinavian Latin sources. Ívarr is not portrayed as physically defending his grave-mound against incursions - indeed, it appears as though his perfectly preserved corpse is entirely defenseless against William the Conqueror's assault. Rather, Ívarr's inhumed body is thought to somehow prevent foreign armies from invading and occupying

\footnotetext{
${ }^{14}$ ‘Furðu seint fúna menn í sandinum. Ekki myndi svá vera, ef hann hefði í moldu legit.’ Bjarni Aðalbjarnarson, ed., Heimskringla II, Íslenzk fornrit 27 (Hið íslenzka fornritafélag, Reykjavík 1945), 404.

${ }^{15}$ George Broderick, ed. and trans., Cronica Regum Mannie \& Insularum: Chronicles of the Kings of Man and the Isles, BL Cotton Julius Avii, $3^{\text {rd }}$ edition (Isle of Man: Manx National Heritage, 2004), f.34r-f.34v.
} 
England. This is a very different expression of the concept of the territorial dead, who are usually concerned only with protecting their grave or their former property, as in the case of VígaHrappr discussed above. While there is evidence from medieval Iceland for belief in supernatural protection of the island's borders, it manifests far differently from that demonstrated by Ívarr's corpse. Landnámabók refers to a law requiring that the figureheads of ships must be removed as the vessel approaches Iceland's shores, lest the landvattir be disturbed, and Óláfs saga Tryggvasonar depicts them warding the island from a foreign king's wizard, whose attempts to approach are thwarted by four landvoettir in the form of a giant, an ox, an eagle, and a dragon. ${ }^{16}$ To the best of my knowledge, Ívarr is the only revenant tasked with defending an entire island in the Old Icelandic corpus.

The peculiarity of Ívarr's burial has not gone unnoticed. Rory McTurk, in his monograph on the sources of Ragnars saga, states of the description of Ívarr's burial that 'it seems indeed to have no very convincing parallel elsewhere in the Ragnarr loðbrók tradition'. ${ }^{17}$ This has prompted critics to seek other possible sources that may have influenced the author of the saga on this point. In the most recent full-length study of the development of the Ragnarr legend, Elizabeth Ashman Rowe suggests that the motif of Ívarr's burial is borrowed from AngloNorman traditions concerning the burial of Harold Godwinson. ${ }^{18}$ Carmen de Hastingae Proelio, composed by Guy, Bishop of Amiens, in the half decade following the Norman Conquest, describes how William the (recent) Conqueror claims the body of Harold Godwinson. Harold's mother asks for her son's body, even offering Harold's weight in gold in exchange, but William refuses: 'Set dux iratus prorsus utrumque negat,/ Iurans quod pocius presentis littora portus/ Illi

${ }^{16}$ Jakob Benediktsson, ed., Íslendingabók, Landnámabók, Íslenzk Fornrit 1 (Reykjavík: Hið Íslenzka Fornritafélag, 1968), 313, 333; Bjarni Aðalbjarnarson, ed., Heimskringla I, Íslenzk fornrit 26 (Reykjavík: Hið íslenzka fornritafélag, 1941-51), 270-72.

${ }^{17}$ Rory McTurk, Studies in Ragnars saga loðbrókar and its Major Scandinavian Analogues, Medium Aevum Monographs, New Series 15 (Oxford: Society of the Study of Mediaeval Languages and Literature, 1991), 246. There is another reference to the belief in Ívarr's protection and William's burning his body in the thirteenth-century Hemings páttr Áslákssonar. I discuss this text below.

${ }^{18}$ Commenting on this passage in Ragnars saga, Rowe states that the "practice of boundary burial for protection against enemies is not a Scandinavian one. Instead, it was found among the Irish, the Welsh, and the early Anglo-Saxons, yet another indication of English influence on the Ragnarr legend.' Rowe, Vikings in the West, 240-41. See also Elisabeth M. C. van Houts, 'Scandinavian Influence in Norman Literature of the Eleventh Century', Anglo-Norman Studies: Proceedings of the Battle Conference 6 (1983), 107-21: 11-12. 
committet, aggere sub lapidum. ${ }^{19}$ (the duke, enraged, refused both requests on the spot, swearing he would sooner put him in charge of the shore of that very port — under a heap of stones. ${ }^{20}$ ) At his command Harold is entombed atop a cliff, and a relative of Harold inscribes a tombstone with the epitaph 'Per mandata ducis rex hic Heralde quiescis,/ Vt custos maneas littoris et pelagi. ${ }^{21}$ ('You rest here, King Harold, by order of the duke, so that you may still be guardian of the shore and sea. ${ }^{22}$ ) William of Poitier's Gesta Guillelmi also records this tradition, though it is not clear whether this was based on shared knowledge of an oral tradition or the result of borrowing between the texts: 'Dictum est illudendo, oportere situm esse custodem littoris et pelagi, quae cum armis ante uesanus insedit... "et in littoreo tumulo iaces, et posthumae generationi tam Anglorum quam Normannorum abominabilis eris." (It was said in jest that he should be placed as guardian the shore and sea, which in his madness he had once occupied with his armies... 'you lie in a tumulus on the seashore and will be an abomination to future generations of English no less than Normans.' $)^{23}$

The parallels between Ívarr's burial and that of Harold Godwinson are compelling, but there are important differences. While both texts have William the Conqueror handling the corpse, in Ragnars saga he violates the burial mound and destroys the corpse, whereas the Carmen de Hastingae Proelio has him collecting Harold's body and providing a tomb for him. William's charging the defeated Harold to guard the borders of the kingdom that he lost should probably not be read as a true guardianship, in any case; the most recent editor of the text regards the inscription as 'a satirical epithet', ${ }^{24}$ and it is tempting to read William's injunction as an intentional slight, a way to dishonor his rival by forcing him to eternally stand vigil over something he already lost, a final insult inscribed upon the landscape. It seems plausible to me that William's burying of Harold Godwinson in this fashion could be informed by a tradition similar to that of Ívarr's burial, but I do not think that the account of Ívarr's burial could itself derive directly from the tradition of Harold Godwinson's burial, as too many important details in

${ }^{19}$ Frank Barlow, ed. and d trans., The Carmen de Hastingae Proelio of Guy Bishop of Amiens (Oxford: Clarendon Press, 1999) 34, 11. 583-84.

${ }^{20}$ Barlow, Carmen, 35.

${ }^{21}$ Barlow, Carmen, 34, 11. 591-92.

${ }^{22}$ Barlow, Carmen, 35.

${ }^{23}$ R. H. C. Davis and Marjorie Chibnall, eds. and trans., The Gesta Guillelmi of William of Poitiers (Oxford: Clarendon Press, 1998), 140-41.

${ }^{24}$ Barlow, Carmen, lxxxv. 
Ragnars saga are absent from Anglo-Latin texts. However, these sources do show that even within the first decades after the Norman Conquest, William is being associated with the burial of defeated kings on Britain's coast, which association may reflect the relationship between haug-brot and the transfer of power, as discussed earlier.

In 1928, Jan de Vries noted the strong similarities between Ívarr's death and burial and descriptions of the death of Vortimer, eldest son of Vortigern, which occur in the Historia Brittonum of Nennius and Geoffrey of Monmouth's Historia Regum Brittanniae: 'Man erkennt leicht, auch in diesem nordischen Gewande, die keltische Sage von Vortigern. Es ist sehr unwahrscheinlich, daß dieser Zug auf literarischem Wege in die skandinavische Sage gekommen sei' ${ }^{25}$ (One can easily see, even in this Nordic guise, the Celtic legend of Vortigern. It is very doubtful that this account entered the Scandinavian material via literary transmission). In his monograph on the sources of Ragnars saga, Rory McTurk follows de Vries'suggestion, stating that 'the motif of the burial-mound giving protection against invasion first became attached to Ívarr/Inwære in England among Scandinavian settlers, surely the most likely environment for the development of a story in which a Viking leader seems to be presented as a guardian spirit of the English people'. ${ }^{26}$ A runic inscription found in Mæshowe refers to the sons of Loðbrók, showing knowledge of the Ragnarr legend in mid-twelfth-century Orkney, ${ }^{27}$ and de Vries proposes that the Orkneys may have been a route of transmission for this material to travel from Scandinavian communities in Britain to Iceland. I shall return to this point later.

How closely does Ragnars saga correspond to the accounts of Vortimer's death and burial? The earliest description of Vortimer's final days is found in the early-ninth-century Historia Brittonum, though it has been argued that the section in which it occurs may be considerable older. ${ }^{28}$ Vortimer successfully drives the Anglo-Saxon invaders from Britain's shores, but his victory will not last:

25 Jan de Vries, 'Die westnordische Tradition der Sage von Ragnar Lodbrók'. Zeitschrift für deutsche Philologie 53 (1928), 257-302: 260.

${ }^{26}$ McTurk, Studies in Ragnars saga, 247. See also Neils Lukman, 'Ragnar loðbrók, Sigfrid, and the Saints of Flanders', Mediaeval Scandinavia 9 (1976), 7-50: 40.

27 de Vries, 'Die westnordische Tradition', 258-63.

Michael P. Barnes, The Runic Inscriptions of Moeshowe, Orkney, Runrön 8 (Uppsala: Institutionen för nordiska språk, Uppsala universitet, 1994), 182-6.

${ }^{28}$ Concerning the so-called Kentish Chronicle, the editor states that 'a narrative so rational is unlikely to have been composed much later than the $6^{\text {th }}$ century.' John Morris, Nennius: British History and the Welsh Annals (London and Chichester: Phillimore, 1980), 4. 
Ille autem post modicum intervallum mortuus est et ante mortem suam ad familiam suam dixit ut sepulchrum illius in portu ponerent a quo exierant, super ripam maris, 'in quo vobis commendo: quamvis in alia parte portum Brittanniae teneant et habitaverint, tamen in ista terra in aeternum non manebunt.' Illi autem mandatum ejus contempserunt et eum in loco in quo imperaverat illis non sepelierunt. In Lincolnia enim sepultus est. At si mandatum eius tenuissent, procul dubio per orationes sancti Germani quicquid pecierant obtinuissent. $^{29}$

(But Vortimer soon after died. Before he died he told his followers to set his tomb by the coast, in the port from which (the English) had departed, saying, 'I entrust it to you.

Wherever else they may hold a British port or may have settled, they will never again live in this land.' But they ignored his command and did not bury him where he had told them: for he is buried in Lincoln. But if they had kept his command, there is no doubt that they would have obtained whatever they wished through the prayers of saint Germanus.) $)^{30}$

Vortimer's demise is given more elaborate treatment in Geoffrey of Monmouth's Historia Regum Brittanniae (hereafter HRB), completed c. 1138. Here his cause of death is poison, administered by his Anglo-Saxon stepmother, Renwein. When Vortimer realized that he was dying,

Nec mora, iussit omnes milites suos uenire ad se et indicata morte quae superueniebat distribuit eis aurum atque argentum suum et quicquid attaui congesserant. Flentes quoque et eiulantes consolabatur, docens uiam universae carnis esse quam initurus erat. Audaces autem et bellicosos iuuenes qui ei in debellationibus suis astare solebant hortabatur ut pro patria pugnantes eam ab hostili irruptione tueri niterentur. Audatia autem maxima docente, iussit piramidem fieri sibi aeriam locarique in portu quo Saxones applicare solebant, corpus uero suum, postquam defunctum foret, sepeliri desuper, ut uiso busto barbari retortis uelis in Germaniam redirent; dicebat enim neminem illorum audere propius accedere si etiam bustum ipsius aspicerent. O maximam uiri audaciam, qui eis quibus uiuus terrori fuerat post obitum etiam ut timeretur optabat! Sed defuncto illo aliud

${ }^{29}$ John Morris, ed. and trans, Nennius: British History and the Welsh Annals, Arthurian Period Sources 8 (London: Phillimore, 1980), 72.

${ }^{30}$ Morris, Nennius, 32. 
egerunt Britones, quia in urbe Trinouantum corpus illius sepelierunt. ${ }^{31}$

(Without delay he ordered all his knights to his side and, telling them of his impending death, gave them all the gold and silver amassed by himself and his ancestors. They wept and wailed, but he comforted them, reminding them that he, like all men, was doomed to die. He begged the bold and warlike youths who had been with him in his battles to fight for their country in order to protect it from enemy invasion. His own great courage inspired him to order that a lofty pyramid be built in the port where the Saxons used to land, at the summit of which his body was to be entombed after his death so that the barbarians would see his place of burial and sail straight back to Germany; he said that none of them would dare to approach any nearer once they had merely glimpsed his tomb. The boldness of that man, who even after death wished to terrorise those who had feared him while he lived! Yet after he died, the Britons did differently and buried his body at Trinovantum [London]). ${ }^{32}$

Though he does not say so explicitly, presumably de Vries was thinking of Viking Age settlements in the Danelaw as the time and place in which this aspect of the traditions concerning Vortimer's death became attached to Ívarr. This would require that an account of Vortimer's death and burial was circulating, probably orally, among Scandinavian settlers in England. If so it has left no other trace, and there is no mention of Vortimer's burial in any extant Anglo-Saxon source; it was not until Geoffrey wrote $H R B$ in the twelfth-century that the English (by now Anglo-Normans) paid heed to Vortimer.

Niels Lukman has also considered the possible influence of Vortimer's death on the development of Ragnars saga. Pointing out that Ívarr is linked with York in Knútsdrápa and that Geoffrey connects a figure named Ivor to York, Lukman argues that a traditional association between Ívarr and York must predate the writing of Geoffrey's HRB. Lukman also points to associations between the Sybil and a character named Ivor in the $H R B$, and the demonic war-cow Sibilia that accompanies a Swedish king into battle and is killed by Ívarr in Ragnars saga. In the saga, the king of Sweden goes into battle accompanied by a demonic cow, which is slain by Ívarr. At the close of $H R B$, Cadualadrus, a British king, is driven from his kingdom by the Anglo-

\footnotetext{
${ }^{31}$ Michael D. Reeve, ed., and Neil Wright, trans., Geoffrey of Monmouth: The History of the Kings of Britain (Woodbridge: Boydell Press, 2007), 133.

${ }^{32}$ Reeve and Wright, Geoffrey of Monmouth, 132.
} 
Saxons. He contemplates returning to Britain to try to retake the island, and the prophecies of an eagle, Merlin, and the Sybil are consulted. It is concluded that Cadualadrus should stay on the continent, and go on pilgrimage to Rome, but his son Ivor and his nephew Yni return to Britain to (unsuccessfully) fight the Anglo-Saxons. In Lukman's view, '(T)he fact that Geoffrey and the Loðbrók-tradition use the same fanciful elements in relation to Ívarr in England, and that neither one of these two versions can be derived from the other, suggests the use of sources held in common by both.' He proposes that a version of Nennius's Historia Brittonum, available in the library of St. Bertin in Flanders, was the inspiration for Ívarr's burial.

However, the parallels that Lukman argues are instances of a pre-existing 'Loðbróktradition' that has been incorporated into $H R B$ are not, to my mind, entirely convincing. Admittedly, a character named Ivor is connected to York in $H R B$, but he appears as one of twenty sons fathered on twenty wives by Ebraucus, a king of Britain who founds York. He is mentioned only once, in the middle of the list, and his name is not elaborated upon. I find it uncontroversial to suppose that the strong Scandinavian links with York in the Viking Age may have prompted Geoffrey to include a Scandinavian name in the list of Ebraucus's sons, nor is it impossible that the historical Ívarr, or traditions concerning him, were known to Geoffrey, and influenced him in choosing the name 'Ivor' for one of Ebraucus's sons. However, Ivor appears in the middle of a long list that includes other historical names such as Brutus and Hector, suggesting that he did not loom especially large in Geoffrey's imagination. Lukman's other suggested parallel, between the Sybil/Ivor in HRB and Ragnars saga's Sibilia and Ívarr, is not, in my view, convincing; it is possible that Geoffrey was thinking of Ívarr or other Scandinavian invaders of England here, but there is nothing remotely bovine about Geoffrey's Sybil. At any rate, if Geoffrey is deliberately drawing on Scandinavian traditions about Ívarr, he has gone to some lengths to obscure his sources. Nor must we assume that even if Geoffrey were influenced by traditions associating Ívarr with York or was aware of the Sibilia who features in Ragnars saga, that a later Icelandic author could therefore not have been influenced in turn by the $H R B$. Influence does not flow in a single direction.

Could the Old Norse translation of $H R B$ have been the means by which the motif of the protective burial came to be integrated into the Ragnarr tradition? Perhaps, but while the extant translations include the poisoning of Vortimer by his stepmother (perhaps a detail too salacious to omit), the text omits any reference to his burial, stating only that Vortigern resumed the 
kingship after his son's death. ${ }^{33}$ There is reason to think that medieval Icelanders had access to this tradition in the Latin source-text, but no evidence that it attracted any particular interestunless, of course, it was the source of Ívarr's burial.

There is a flaw running through the arguments that accounts of the burials of Vortimer or Harold Godwinson, as they are extant in Cambro- and Anglo-Latin sources, lie directly behind Ívarr's burial in Ragnars saga. The Latin texts, while clearly working within the same broad paradigm of protective burial as is found in Ragnars saga, differ from the saga account in one crucial detail: namely, Ívarr's command is carried out and he is buried where he requested, and his body successfully wards off invasion for several centuries, before someone arrives on the scene who knows how to break his protection. This discrepancy, while significant, does not rule out the possibility that Ívarr's burial was modeled on that of Vortimer or Harold, but it does suggest casting a slightly wider net in the search for potential sources and analogues.

What has not, as far as I am aware, attracted comment is that the motif of protective burial in Ragnars saga bears a much closer resemblance to burials described in several Middle Welsh sources than to any of the Latin texts discussed above. ${ }^{34}$ Descriptions of strikingly similar burials are found in two Middle Welsh prose texts. The most detailed account occurs at the conclusion of Branwen, the $2^{\text {nd }}$ Branch of the Mabinogi. The tale is set in a legendary, preRoman Britain, and concerns the family of Brân, a giant and king of the entire island.

After a marriage alliance between Brân's sister Branwen and the king of Ireland sours, the Britons invade Ireland. The ensuing battle is devastating on both sides. Brân is mortally wounded in Ireland, and he commands his men to decapitate him and return his head to Britain: “"A chymerwch chwi y penn, heb ef, 'a dygwch hyt y Gwynuryn yn Llundein, a chledwch a'y

33 Jón Sigurðsson, ed., Trójumanna saga ok Breta sögur, in Annaler for Nordisk Oldkyndighed og Historie (1849), 3-145, at 8. Finnur Jónsson and Eiríkur Jónsson, eds., Bretasögur, in Hauksbók, udg. efter de Arnamagnoeanske håndskrifter no. 371, 544 og 675, 4, samt forskellige papirshåndskrifter af det Kongelige nordiske oldskrift-selskab (København: Thiele, 1892-96), 231-302, at 270 .

${ }^{34}$ Lukman does make a parenthetical reference to Branwen in passing when discussing the parallels with Vortimer, but at no point does he suggest that Branwen could have influenced Ragnars saga, and he appears to be unaware of the versions of the motif occurring in the Trioedd Ynys Prydein; his argument is focused exclusively on the versions of Vortimer's burial found in Historia Brittonum and HRB. Lukman, 'Ragnar loðbrók', 40. 
wyneb ar Freinc ef.", 35 ('And take the head,' he said, 'and bring it to White Hill in London, and bury it with its face towards France.') Brân further informs his men that before burying his head, they will feast at Harlech for seven years, and then at Gwales in Penfro for eighty years, but that after that they must take his head to London and bury it. Events transpire as he had predicted, and the text relates that 'hwnnw uu y trydyd matcud ban gudywyt, a'r trydyd anuat datcud pann datcudywyt; cany doey ormes byth drwy uor y'r ynys honn, tra uei y penn yn y cud hwnnw. ${ }^{36}$ (that was one of the Three Fortunate Concealments when it was concealed, and one of the Three Unfortunate Disclosures when it was disclosed; for no oppression would ever come over the sea to this island, while the head was in that concealment.) The formulaic manner in which this statement is introduced indicates that this event was included in the Trioedd Ynys Prydein 'Triads of the Island of Britain', a catalogue of names and events from medieval Welsh tradition, and the triad recounting the burial and exhumation of Brân's head survives in two versions.

In the triad, Brân and Vortimer are joined by a pair of dreigeu 'dragons', which also appear in Historia Brittonum, HRB, and Lludd a Llefelys. The simpler version of the triad refers to both the chud 'concealment' and the datcud 'disclosure', but only describes the circumstances of the former:

37. Tri Chud a Thri Datcud Enys Prydein:

Penn Bendigeituran mab Llyr, a gladwyt yn y G6yn6ryn yn Llundein. A hyt tra vei y Penn yn yr ansa6d yd oed yno, ny doy Ormes byth y'r Enys hon;

Eil, Esgyrn G6ertheuyr 6endigeit a gladwyt ym pryf byrth yr Enys hon; Trydyd, y Dreigeu a gladwys Llud mab Beli yn Dynas Emreis yn Eryri.

(37. Three Concealments and Three Disclosures of the Island of Britain:

The Head of of Bendigeidfran, son of Llŷr, which was buried in the White Hill in London. And as long as the Head was there in that position, no Oppression would ever come to this Island;

${ }^{35}$ Derick S. Thomson, ed., Branwen Uerch Lyr (Dublin: Dublin Institute for Advanced Studies, 1986), 15.

${ }^{36}$ Thompson, Branwen, 17. 
The second: the Bones of Gwerthefyr the Blessed, ${ }^{37}$ which were buried in the Chief Ports of this Island;

The third: the Dragons which Lludd son of Beli buried in Dinas Emrys in Eryri.) ${ }^{38}$

That Brân's burial failed to protect Britain from invaders is evident to anyone with even the most cursory knowledge of insular history; medieval Welsh literati explained this inconsistency by claiming that King Arthur, who would not permit the land to be defended by another's strength, had the head exhumed. (The outcome of this action was, we must assume, a disappointment to Arthur in the end.) The account of Arthur's interference is found in a double triad in Llyfr Goch Hergest 'The Red Book of Hergest':

37 R. Tri Matkud Ynys Prydein:

Penn Bendigeituran uab Llyr, a guduwyt yn y G6ynuryn yn Llundein, a'e wyneb ar Ffreinc. A hyt tra uu yn yr ansa6d y dodet yno, ny doei Ormes Saesson byth y'r Ynys honn;

Yr eil Matkud: y Dreigeu yn Ninas Emreis, a gudya6d Llud uab Beli;

A'r trydyd: Esgyrn G6ertheuyr Uendigeit, ym prif pyrth yr Ynys honn. A hyt tra vydynt yn y kud h6nn6, ny doei Ormes o Saesson byth y'r Ynys honn.

A llyna y Tri Anvat(dat)kud pan datgudwyt: A G6rtheyrn G6rtheneu a datkudyawd Esgyrn G6ertheuyr Uendigeit yr serch gvreic. Sef oed honno, Ronn6en baganes; Ac ef a datkudya6d y Dreigeu;

Ac Arthur a datkudya6d Penn Bendigeituran o'r G6ynnvrynn. Kan nyt oed dec ganta6 kad6 yr Ynys honn o gedernit neb, namyn o'r eidaw ehun.

(Three Fortunate Concealments of the Island of Britain:

The Head of Bendigeidfran, son of Llŷr, which was concealed in the White Hill in London, with its face towards France. And as long as it was in the position in which it was put there, no Saxon Oppression would ever come to this Island;

The second Fortunate Concealment: the Dragons in Dinas Emrys, which Lludd son of

${ }^{37}$ On the significance of the epithet bendigeit 'blessed', see Glenys Goetinck, 'The Blessed Heroes', Studia Celtica 20/21 (1985), 87-109.

${ }^{38}$ Rachel Bromwich, Trioedd Ynys Prydein: The Triads of the Island of Britain, 3rd. ed. (Cardiff: University of Wales Press, 2006), 94. 


\section{Beli concealed;}

And the third: the Bones of Gwerthefyr the Blessed, in the Chief Ports of this Island. And as long as they remained in that concealment, no Saxon Oppression would ever come to this Island.

And they were the Three Unfortunate Disclosures when they were disclosed.

And Gwrtheyrn the Thin disclosed the bones of Gwerthefyr the Blessed for the love of a woman: that was Rhonwen the pagan woman;

And he disclosed the Dragons;

And Arthur disclosed the head of Bendigeidfran (Brân the Blessed) from the White Hill, because it did not seem right to him that this Island should be defended by the strength of anyone, but by his own. $)^{39}$

The accounts of Vortimer's death and burial as found in the Latin and Welsh sources do bear some similarity to that of Ívarr, in that a dying king asks his followers to bury his body to guard the island of Britain against overseas invaders; however, until we come the Trioedd, the idea that Vortimer's body would somehow physically prevent invaders from setting foot on Britain's shores does not occur. In none of the versions is his body described as being preserved. In the earlier, Latin versions his men do not follow his orders, and in the Welsh account of Vortimer's burial his body is dismembered and his bones divided among the ports. The parallels with the burial of Brân are much closer:

a) Burial is carried out according to the wishes of the dying king

b) Supernatural preservation of the corpse: Brân's head can talk and doesn't decay while feasting in the Otherworld (it is unclear what happens after he is buried); Ívarr's corpse remains whole until he is burned

c) Successful protection: both Brân's head and Ívarr's corpse are said to guard Britain/England until exhumation

d) Corpse/head must be physically destroyed or removed to destroy its power

e) Removal of protection results in invasion by an enemy from the continent f) 'William of Normandy' connection: This is explicitly the case in Ragnars saga, and arguably implicit in Branwen and the Trioedd (head buried in London, facing towards France)

${ }^{39}$ Bromwich, Trioedd, 94-5. 
It is not out of the question that the motif of Vortimer's thwarted burial could have become attached to both Brân and Ívarr and developed along similar lines, but it strikes me as unlikely that two independent elaborations upon this theme of protective burial would adhere so closely in significant details, especially when being translated into such distinct cultural milieus. Even in the version of Vortimer's burial in the triad, where he is successfully (if briefly) buried, his bones are exhumed immediately by his father at the urging of his murderer, while both Brân and Ívarr ward Britain/England for centuries until exhumed. ${ }^{40}$

For reasons of space I will not delve too deeply into the background of the motif of protective burial as it occurs in Branwen and the triad, but a brief overview of its age and development are relevant to the current argument, in order to establish a possible chronology for its borrowing into Old Norse. ${ }^{41}$ Commenting on the Triads, Rachel Bromwich describes these as 'talismanic burials', and she notes "striking parallels" between the burials of Vortimer and Brân with several royal burials recorded in medieval Irish sources, where burying the dead standing and armed on a border facing towards the enemy, and this is described as a pagan custom. ${ }^{42}$ Elizabeth O'Brien also connects the burials of Brân and Vortimer with these Irish burials, and she argues that while there is no archaeological evidence for this type of burial in Ireland, she proposes that the the Irish descriptions may have been modeled on a particular Anglo-Saxon pagan burial practice, in which men equipped with weapons are buried on a territorial border, oriented so that they face the neighboring territory. ${ }^{43}$ Thomas Charles-Edwards has proposed that Brân's and Vortimer's burials might reflect a similar way of thinking to that found in a medieval Irish legal practice for claiming land to which one has a hereditary claim. The procedure has several stages, but the relevant portion has the claimant leading yoked horses onto the claimed

\footnotetext{
${ }^{40}$ The Welsh sources display a certain amnesia concerning the Roman invasion on this point, and in the Trioedd there is some evidence that an earlier tradition of a Roman gormes 'invasion' has been replaced with more fantastical afflictions Bromwich, Trioedd, 92-3, 141. A tradition developed, related most fully in Breudwyt Maxen Wledic, that Britain was brought into the Roman empire peacefully, through a marriage alliance. Brynley F. Roberts, ed., Breudwyt Maxen Wledic, Mediaeval and Modern Welsh Series 11 (Dublin: DIAS, 2005).

${ }^{41}$ There are some correspondences between the Welsh material on protective burial and several early Irish texts, where a dead man is buried on a boundary between kingdoms, but there is no evidence that the Irish sources were a direct influence on any of the texts under discussion here. See Bromwich, Trioedd, 95-6.

${ }^{42}$ Bromwich, Trioedd, 95-6.

${ }^{43}$ Elizabeth O’Brien, 'Early Medieval Sentinel Warrior Burials', Peritia 20 (2008), 323-30.
} 
land by entering over a boundary marked by a grave mound or mounds. Charles-Edwards proposes that the ritual reflects an idea that if the man does not, in fact, have a hereditary claim to the territory, the person or persons buried in the grave would somehow manifest their disapproval and prevent the newcomer from gaining entry onto the land. ${ }^{44}$ Medieval Welsh law codes do not contain similar practices, and Charles-Edwards speculates that this may be a result of the Welsh texts being comparatively late in comparison with the Irish: by the time the Welsh laws has we have them were written, burial practices had long since shifted to burial in churchyards.

All of this raises the question: how old is the tradition of Brân's head and its supernatural protection over the borders of Britain? It has been suggested that the medieval accounts of Brân's and Vortimer's burials originated in pre-Christian burial practices. Observing that the northernmost of the British forts on the Saxon Shore was named Branodunum 'the fort of Brân', John Koch argues that it must have been associated with Brân, whom he views as having been a death god whose fort guarded the coastline. This would push the connection between Brân and protective burial to the fourth century AD. This is an elegant explanation, especially given that the forts protected against Anglo-Saxon invaders, and the triad in Llyfr Goch Hergest implicitly links the removal of Brân's head with the Anglo-Saxon settlement of Britain. ${ }^{45}$ However, 'brân' was also a common noun meaning "raven" (becoming "crow" in Modern Welsh), and 'fort of ravens' is also a possible interpretation of Branodunum. John Carey has gone so far as to argue that the narrative of Brân's voyage to Ireland, if not the figure himself, was based on narratives brought to Wales from Ireland in the early Middle Ages; ${ }^{46}$ at the least, the author of Branwen is self-consciously hibernicizing his narrative. There is no evidence, textual or otherwise, that the narratives of these specific burials in the Trioedd derive directly from pre-Christian myth, although it is certainly possible that the general theme is very old. As the three burials described in the triad are all related in some way to the settlement of Anglo-Saxons in Britain, it is

\footnotetext{
${ }^{44}$ T. M. Charles-Edwards, 'Boundaries in Irish Laws', in Medieval Settlement: Continuity and Change, ed. P. H. Sawyer (London: Edward Arnold, 1976), 83-7.

45 John Koch, 'Brân, Brennos: An Instance of early Gallo-Brittonic History and Mythology', Cambrian Medieval Celtic Studies 20 (1990), 1-20; John Koch, 'Some Suggestions and Etymologies Reflecting upon the Mythology of the Four Branches', Proceedings of the Harvard Celtic Colloquium 9 (1989), 1-11: 8-9.

${ }^{46}$ John Carey, Ireland and the Grail (Aberystwyth: Celtic Studies Publications, 2007), 43-98.
} 
probable that they developed after this event, as opposed to having been pre-existing narratives that were altered to fit the historical record.

It cannot be ruled out that the depiction of Vortimer's burial in the triad records a genuine, early tradition that is distorted in the Latin sources, but if so, why omit the burial in the Latin sources? It is likely that the tradition of Vortimer's burial in the ports of Britain is a later development, taking place after the Historia Brittonum was composed in the early ninth century, perhaps influenced by or developed in tandem with the Brân tradition, rather than an earlier, 'primitive' version, as Rachel Bromwich suggests. ${ }^{47}$ That the motif is British in origin seems to me beyond doubt, and I would argue that there is a clear line of development from the Historia Brittonum account of Vortimer's death to the burial of Brân in Branwen can be observed. Furthermore, the Brân narrative elaborates upon, and, I suggest, applies a mythological overlay to the Vortimer narrative, adding the element of supernatural protection to what, in the Latin sources about Vortimer, is merely intended to be a deterrent in that it is a reminder of past defeats. It is only in the later, Welsh tradition that supernatural guardianship is explicitly presented as the purpose of Vortimer's burial, and given that it is specified in the triad that it is Gwerthefyr's bones that are buried, it would be ironic indeed if his death was the inspiration for Ívarr beinlausi's burial.

It is not possible to establish the route of transmission of the burial motif from Britain to Iceland with certainty, but I will consider a few possibilities. As Rowe makes clear, the development of the legends surrounding Ívarr and his family was still very much ongoing in the twelfth century. I quote at length:

(a)ssuming that all the motifs with parallels in the English works dealing with Ragnarr or his son did indeed arise in England between the late $9^{\text {th }}$ century and the early $11^{\text {th }}$ century, it means that they travelled to Norway and Iceland rather than to Denmark, and that they did so early enough that they could have been incorporated into the legend of Ragnarr loðbrók before 1215, when Saxo used this legend for Book IX of the Gesta Danorum. Furthermore, as the legend also seems to have absorbed motifs from Geoffrey of Monmouth's Historia regum Britanniae, which was written around 1136, the period in which the legend developed can be narrowed to the second half of the $12^{\text {th }}$ century. An

\footnotetext{
${ }^{47}$ Bromwich, Trioedd, 98.
} 
influx of English texts and traditions at this point is to be expected, as this is a period of considerable interaction between the clerics of Norway and England. ${ }^{48}$

How does this chronology correspond to the Welsh sources? Branwen, along with the other Three Branches of the Mabinogi, is extant in two fourteenth-century manuscripts, and there are also fragments of Branwen in an early thirteenth-century manuscript. The earliest manuscripts of the Trioedd are dated to roughly the same period. The questions of the authorship and dating of the Pedeir Keinc y Mabinogi ${ }^{49}$ 'Four Branches of the Mabinogi' are by no means settled, but the scholarly consensus is that while the four texts contain much earlier material, they took the shape in which they are known to us at some point in the late eleventh or twelfth century. The First and Third Branches are set in southern Wales, in Dyfed, but the other Branches take place primarily in northern Wales: the Fourth Branch, Math uab Mathonwy, deals with the ruling family of Gwynedd, and while Brân is ostensibly king of all Britain, most of the Britain-based action in Branwen is concentrated on the west coast, primarily in the north-west: the tale begins at Harlech, in Gwynedd, and Branwen's heart breaks from grief in Anglesey, where she is buried.$^{50}$ Given the knowledge of Welsh geography in the texts, it is probable that at least Branwen and Math were originally composed in Gwynedd. ${ }^{51}$ That the Four Branches form a cohesive whole in the manuscripts where they occur is clear from intertextual references among the four tales.

There is ample evidence for cultural connections between Wales and Norse-speaking populations during and after the Viking Age. Wales was subject to Viking raids during the ninth and tenth centuries, and Wendy Davies has argued that the combined evidence of place-names, grave goods, hoards, and 'Scandinavian motifs' on stone sculpture indicates Scandinavian settlement in Wales, especially in the north-west and north-east (1990, 50-6); she also argues that areas of Gwynedd were under Scandinavian control from 960 to $1025 .^{52}$ That the accounts of

\footnotetext{
${ }^{48}$ Rowe, Vikings in the West, 108-9.

${ }^{49}$ It is not known whether there were ever more than four 'branches', nor what mabinogi means in this context.

${ }^{50}$ Patrick Sims-Williams, 'Clas Beuno and the Four Branches of the Mabinogi', in 150 Jahre 'Mabinogion: Deutch-Walische Kulturbeziehungen, eds. Bernard Maier and Stefan Zimmer with Christine Bakte (Tübingen: Walter de Gruyter, 2001), 111-127: 112-14.

${ }^{51}$ Brynley F. Roberts, 'Where were the Four Branches of the Mabinogi Written?' in The Individual in Celtic Literature, CSANA Yearbook 1, ed. Joseph Falaky Nagy (Dublin: Four Courts Press 2001), 61-73: 68.

${ }^{52}$ Wendy Davies, Patterns of Power in Early Wales (Oxford: Oxford University Press, 1990), 58-9.
} 
Brân's and Ívarr's deaths are so similar is made more interesting by the fact that since the late nineteenth century, critics have pointed out numerous parallels between Branwen and Germanic heroic legend, in particular the Nibelung/Vọlsung tradition and Hrólfs saga kraka. ${ }^{53}$

Alaric Hall has argued that some of the motifs found in both Branwen and the Germanic material were borrowed from Welsh, but that in other instance the evidence suggests that the Welsh narrative has borrowed from Scandinavian sources, concluding that 'in any case, the transmission of the material shared between Hrólfs saga and Branwen was almost certainly oral, and could have taken place at any time centuries before texts were first written' ${ }^{54}$ It has also been observed that Sigrgards saga froekna contains material that resonates with the plot of Branwen: just as the Irish hide warriors in bags in the hall, in the saga men are concealed behind the wall paneling in a hall, causing the wall coverings to bulge outwards. A hunchback crushes the concealed men by grinding his back against the walls. The editors of the most recent edition and translation of the text discuss this parallel and others that have been proposed, stating that: '(r)ather than direct literary influence, however, we are presumably seeing Icelandic adoption of narrative ideas during a fairly intense period of oral, rather than literary, contact between the Western Scandinavian and Irish Sea cultural zones during the Viking Age and the ensuing century or so'. ${ }^{55}$ Perhaps, but given the lateness of this saga - its earliest manuscript is dated to the fifteenth century — we should be cautious when dismissing the possibility of literary borrowing; a narrative, and even more so a folk motif, may exist in both literary and oral forms simultaneously.

Brent Miles speculates that 'memorized lays' may have been the means by which the relevant motifs circulated among Celtic- and Germanic-speaking communities, but he would place the point at which the Germanic legendary material was brought into the service of the Welsh narrative during a specific historical moment, the reign of Gruffudd ap Cynan (ruled 1081-1137), the half-Welsh/half-Hiberno-Norse king of Gwynedd. Miles argues that it is more

\footnotetext{
${ }^{53}$ The most recent treatments of the parallels are Alaric Hall, 'Gwŷr y Gogledd? Some Icelandic Analogues to Branwen Ferch Lyr', Cambrian Medieval Celtic Studies 42 (2001), 27-50; Brent Miles, 'Branwen: A Reconsideration of the German and Norse Analogues', Cambrian Medieval Celtic Studies 52 (2006), 13-48.

${ }^{54}$ Hall, 'Gwŷr y Gogledd,' 36.

${ }^{55}$ Alaric Hall, Steven D. P. Richardson, and Haukur Porgeirsson, 'Sigrgarðs saga froekna: A Normalised Text, Translation, and Introduction,' Scandinavian-Canadian Studies/Études Scandinaves au Canada 21 (2012-13), 80-155, at 87.
} 
likely that the impetus for this borrowing came from 'Norse presence in Ireland', rather than from continental Germanic sources, and that, depending on the date of Branwen's composition, it may have taken its present form when Dublin still retained a strong Scandinavian presence. ${ }^{56} \mathrm{I}$ am less interested in how Germanic legends came to be so integral to the plot of Branwen than in how Welsh material may have ended up in Ragnars saga, but the milieu in which Miles proposes that this transmission occurred has implications for my argument.

Miles argues that the supposed Scandinavian borrowings in Branwen may have been a deliberate nod to Gruffudd's Scandinavian heritage. Gruffudd was raised in Dublin before he came to Gwynedd to claim what he considered his patrimony. Gruffudd might have learned Middle Welsh, Old Norse, and Middle Irish during childhood, ${ }^{57}$ and his court would have included speakers of Welsh, Old Norse, and Irish. This multilingual community would have allowed the court to enjoy the Irish material on a surface level, but also to appreciate the deeper 'Germanic' currents.

It should be noted that for the parallel under discussion in this essay, we are on firmer ground as far as dating: while Ragnars saga references, however fantastically, historical events of the Viking Age, the section of the text dealing with Ívarr's death and burial must postdate William of Normandy's invasion of England in 1066. If the author/redactor of Branwen drew on Germanic sources to shape the narrative, could an early version of Ragnars saga have influenced the depiction of Brân's burial? The possibility cannot be ruled out, but I think it is highly unlikely; Brân's burial is positioned in Triad 37 as one of several similar burials, and, as discussed above, is probably modifying the verifiably older tradition of Vortimer's burial as found in Historia Brittonum. Branwen refers to the triad, so a version of the triad must predate the extant version of Branwen. The motif of protective burial on borders appears to be insular, and the guarding of an entire island is, with the exception of Ragnars saga, found only in British sources. What evidence is there of contact between medieval Wales and Scandinavian-speaking populations in the second half of the twelfth century, after Gruffudd's death in 1137, the period in which Rowe argues Ragnars saga took shape?

\footnotetext{
${ }^{56}$ Miles, 'Branwen', 45.

${ }^{57}$ Paul Russell, 'Externarum linguarum excellens: the rhetoric and reality of the languages of Gruffudd ap Cynan, ruler of Gwynedd ( $\uparrow 1137)$ ', in Multilingualism in Medieval Britain (c. 1066-1520): Sources and Analysis, eds. Judith A. Jefferson, Ad Putter, and Amanda Hopkins (Turnout: Brepols, 2013), 73-88, at 80-1.
} 
Much of our knowledge about Gruffudd ap Cynan comes from his biography, Historia Gruffudd vab Kenan, which was originally written in Latin, probably in the mid-twelfth-century, and then translated into Middle Welsh. ${ }^{58}$ The text emphasizes Gruffudd's Scandinavian ancestry on his mother's side; her descent is traced back to Haraldr Harfagyr (ON Hárfagri), who is described here as the son of the king of Denmark, and said to have raided Ireland with his two brothers and to have founded the city of Dublin. ${ }^{59}$ The text exhibits a confusion between Haraldr Hálfdanarson 'Hárfagri', the first king to unify Norway, and Haraldr Sigurðarson 'Harðráði', the Norwegian king, half-brother on his mother's side of St. Óláfr (himself a descendant of Haraldr Hálfdanarson), who died invading England in 1066. Judith Jesch argues that the confusion in the Welsh text indicates that Orkney was the source for the Scandinavian material in the Historia Gruffudd, perhaps via the Isle of Man. ${ }^{60}$ David E. Thornton has suggested that the genealogical material in the Historia Gruffudd may be intended to shore up the claims for his son's right to rule, which would put the period for the transmission of the Norse material into Middle Welsh during the reign of his son, Owain (1137-70). ${ }^{61}$ The genealogical section in Gruffudd's biography refers to traditions of Scandinavian settlement in northern Wales: It is said of Óláfr, Gruffudd's maternal grandfather, that in addition to ruling Dublin and an Irish province, he also 'brenhin oed ar lawer o enyssyd ereill, Denmark, a Galwei, a Renneu, a Mon, a Gvyned, en e lle y gwnaeth Avloed castell cadarn a'e dom a'e fos etwa en amlvc, ac a elwit castell Avloed vrenhin; yg Kymraec, hagen, y gelwir Bon y Dom² (was king over many other islands, Denmark, and Galloway, and the Rinns, and Anglesey, and Gwynedd, where Óláfr made a strong castle, and its mound and its ditch are still easily observed, and which was called King

\footnotetext{
${ }^{58}$ It is unclear whether the surviving Latin versions descend from the original Latin text, or are translations of the Middle Welsh versions. Paul Russell has argued that the Latin version in Peniarth 434 was copied from the original Latin text, and not a translation from Middle Welsh. Paul Russell, ed. and tr., Vita Griffini filii Conani: the medieval Latin life of Gruffudd ap Cynan, (Cardiff: University of Wales Press, 2005), 25-34.

${ }^{59}$ D. Simon Evans, ed., Historia Gruffud vab Kenan (Cardiff: University of Wales Press, 1977), $2-4$.

${ }^{60}$ Judith Jesch, 'Norse Historical Traditions and Historia Gruffud vab Kenan: Magnús berfœettr and Haraldr hárfagri', in Gruffudd ap Cynan: A Collaborative Biography, ed. K. L. Maund (Woodbridge, Suffolk: The Boydell Press, 1996), 117-147, at 139-47.

${ }^{61}$ David E. Thornton, 'The genealogy of Gruffudd ap Cynan', in Gruffudd ap Cynan: A Collaborative Biography, ed. K. L. Maund (Woodbridge, Suffolk: The Boydell Press, 1996), 79108: 105-6.

${ }^{62}$ Evans, Historia Gruffud, 2.
} 
Óláfr's Castle; but in Welsh it is called Bon y Dom.) Upon Gruffudd's death, the text states that 'Kymry a Gwyddyl a gwyr Denmark yntwy a ddrygyrferthassant o ddigwyddedigaeth Gruffudd vrenhin, fegis kwynfan yr Iddeon am Ioswe, fab Nwn. ${ }^{63}$ (The Welsh and the Irish and the men of Denmark mourned the death of king Gruffudd, just as the Jews lamented for Joshua, son of Nun). Thus we have a period of flourishing literary culture in north Wales from the mid-eleventh through late-twelfth century, with an enthusiasm for Scandinavian history and geneaology (however spurious), undoubtedly encouraged by, if not originating in, the Hiberno-Norse heritage of Gruffudd ap Cynan.

As mentioned above, de Vries suggested the Orkneys as the route by which the British material, or versions of the Ragnarr legend that had incorporated British or English elements, travelled to Iceland, to be recorded there in Ragnars saga. The Mæshowe inscription mentioning the sons of Loðbrók is dated to around 1150. Háttalykill, composed in Orkney by Rognvaldr jarl Kali Kolson of Orkney and the Icelander Hallr Pórarinsson in the 1140s or 1150s, also contains references to a number of figures central to the Ragnarr tradition in stanzas 11-22: Ragnarr loðbrók himself, his enemy Ælla of Northumbria, Ívarr, and at least three of his brothers. ${ }^{64}$ Ragnarr and his sons were known in mid-twelfth century Orkney, a milieu with strong literary connections to Iceland. One of the poets at Rognvaldr's court in Orkney was Sigmundr ongull Andrésson, whose byname, it has been speculated, may indicate a connection to Anglesey; another Orcadian ruler, Sveinn Ásleifarson, took an Icelandic poet on raiding expeditions along the Welsh coast. ${ }^{65}$ Commenting on the 'learned and poetical interest in Norse myth in twelfthand thirteenth-century Orkney', Jesch muses that '(T)he arrival of a lot of well-trained Icelandic poets in the upwardly mobile, wealthy and vibrant culture of twelfth-century Orkney, spiced by contact with Celtic peoples all around, may just have been the catalyst that sparked an explosion of interest in poetry and mythology which was then quickly transferred back to Iceland and continued to develop there, culminating in Snorri's Edda. ${ }^{, 66}$ As Jesch has proposed, the treatment of Norse genealogical material in Gruffudd's biography suggests an origin in Orkney,

\footnotetext{
${ }^{63}$ Evans, Historia Gruffud, 33.

${ }^{64}$ Rognvaldr jarl and Hallr Pórarinsson, 'Háttalykill' in Kari Ellen Gade and Edith Marold (eds), Poetry from Treatises on Poetics, Skaldic Poetry of the Scandinavian Middle Ages 3. (Turnhout: Brepols), 1001-93; especially 1004-5, and 1019-31.

65 Judith Jesch, The Viking Diaspora (London: Routledge, 2015), 179-80.

${ }^{66}$ Jesch, Viking Diaspora, 149.
} 
and the mid-to-late twelfth century composition of the Historia Gruffudd places the period of likely borrowing in the same decades as Ívarr and his brothers were being etched into the stone of Mæshowe and immortalized in skaldic verse; thus the archipelago emerges as a possible, even likely, route by which Welsh material may have in turn influenced the development of the Ragnarr legend. I should point out that neither Triad 37 nor Branwen contain all of the features of Brân's burial that I am arguing have come to influence Ragnars saga, as the triad omits Brân's dying instructions to his men, and no manuscript of Branwen describes the circumstances of the exhumation. I propose that the narrative may have been circulating in an oral version that included the relevant elements.

There are certainly other paths by which the traditions surrounding the burial of Brân's head may have become attached to the Ragnarr tradition: a recent study has argued that the thirteenth-century Older Law of Västergötland incorporated material from the Welsh Cyfraith Hywel Dda 'Law of Hywel Dda'; ${ }^{67}$ there is also evidence for knowledge of Scandinavian and Welsh legendary material circulating in the West Midlands in the thirteenth century. ${ }^{68}$ Clearly, there were various milieus in which cultural transmission between speakers of Middle Welsh and Old Norse could and did occur, but the interest in the Ragnarr legend in mid-twelfth-century Orkney, and the probably transmission of Scandinavian historical traditions from Orkney to Gwynedd in the same period, makes the Orkney-Gwynedd (or Orkney-Man-Gwynedd) nexus an attractive one for imagining how Middle Welsh narratives might have entered into the Scandinavian cultural sphere.

The literature of medieval Iceland borrows heavily from the literary traditions of the regions with which Scandinavians had extensive cultural contact, and Irish influence on Old Norse literature has long been noted. ${ }^{69}$ On occasion these borrowings are integral to the narrative structure of the Norse text; for example, William Sayers argues for significant Irish borrowings in Njáls saga, and Lindy Brady analyses the borrowing and inversion of an Irish

${ }^{67}$ Lisa Collinson, 'Welsh Law in Thirteenth-Century Sweden: Women, Beasts, and Players', Speculum 92 (2017), 755-86.

${ }^{68}$ Hall, 'Gwŷr y Gogledd', 31.

${ }^{69}$ Gísli Sigurðsson, Gaelic Influence in Iceland: Historical and Literary Contacts. A Survey of Research, $2^{\text {nd }}$ edition (Reykjavík: University of Iceland Press, 2000). 
kingship motif in Laxdoela saga. ${ }^{70}$ While I would certainly not wish to give the impression that I am suggesting that the plot of the English section of Ragnars saga was borrowed wholesale from Branwen, there are significant parallels between the two texts, beyond the death and exhumation of the ruler, and it is possible that preexisting elements of the plot may have been deliberately shaped to echo the Welsh tale. The invasion of England by the historical figures who came to be known as Ragnarr's sons obviously provides the backbone for this section of the saga, but the manner in which their arrival is framed in the text may show signs of Welsh influence.

Branwen and Ragnars saga both feature the invasion of an island undertaken by group of royal brothers, after they receive word by a messenger of a close relative's mistreatment or death at the hands of the island's king: in Branwen, Brân and his brothers invade Ireland with an army after being told that their sisteris being abused by her husband, the Irish king Matholwch; in Ragnars saga, Ívarr and his brothers invade England after learning that their father has been killed in a snake-pit by King Ælla. Brân and Ívarr both receive a gift of land as recompense for the mistreatment of relative: Ælla gives Ívarr land in England on which to build a city, and Matholwch builds Brân a giant-sized house in Ireland. In both texts the foreign king is slain by the brothers after a false peace is established. In the penultimate chapter of Ragnars saga, following the deaths of all of Ragnarr's sons the warriors who had followed them disperse. Two meet again many years later at a funeral feast in a foreign land. In Branwen, after Brân's death but before the burial of his head, his surviving warriors spend several decades as guests at otherworldly feasts, before returning to the mortal world and going their separate ways; two travel together. Significantly, in Ragnars saga the two men are said to be larger in size than the other men gathered at the feast. It is a commonplace of medieval Welsh (as well as Irish) texts that people were significantly larger in the past, but Brân's enormity is emphasized throughout Branwen. Brân and Ívarr are both presented as 'noble pagans', and both have a physical condition that sets them apart: Brân is a giant who has never been in a house, Ívarr is born without bones and must be carried into battle. ${ }^{71}$

\footnotetext{
${ }^{70}$ William Sayers, 'Gunnarr, his Irish Wolfhound Sámr, and the Passing of the Old Heroic Order in Njáls saga', Arkiv för nordisk filologi 112 (1997), 43-66; Lindy Brady, 'An Irish Sovereignty Motif in Laxdcela saga', Scandinavian Studies 88 (2016), 60-76.

${ }^{71}$ For completeness's sake, I mention in passing that Brân, like the historical figure who probably lies behind Ívarr beinlausi, invaded and conquered Ireland, and that both figures are associated with ravens: as mentioned earlier, 'brân' is the Middle Welsh noun for 'raven', and
} 
Curiously, Branwen and Ragnars saga each elide a significant historical invasion and period of foreign rule in their account of the protective burial: the Roman invasion of Britain in the case of Branwen, and the eleventh-century Danish conquest of England in Ragnars saga. Perhaps more striking is the manner in which the political landscape is portrayed in Branwen and Ragnars saga. Both take considerable liberties with the division — or rather, lack of division—of the island into regional kingdoms and territories, and the patchwork kingdoms and territories of pre-Roman Britain and Anglo-Saxon England are superficially collapsed into a single kingdom, in which London is either the capital city, or is founded by the future king, respectively. In Branwen, Brân is the crowned king of London, ruling over Britain, here envisioned as a single, united kingdom. In this Branwen is drawing on a wider Welsh tradition of a united, sovereign kingdom of Britain, but the use of London is interesting, especially give the prominence of London after the Norman Invasion. ${ }^{72}$ Charles-Edwards recently discussed the usage of the phrase 'crowned king of London' in Branwen:

On the one hand, crowning as an attribute of a ruler of Britain betrays assumptions dating from the tenth-century empire of Britain; but, on the other, the role of London is more easily understood as a reference to the Roman past than a late-Anglo-Saxon or AngloNorman present. From the time of Edward the Confessor, Westminster became a major royal centre where kings were crowned; but in contemporary eyes, Westminster was quite distinct from London. It seems, therefore, as if the conception of a of a political unity of Britain was already present in Gildas's De Excidio and was regularly reshaped to accord with contemporary conditions; and yet, it never lost its links with a remote Roman and even pre-Roman past. ${ }^{73}$

At times the author/redactor of the Four Branches displays a certain playfulness in his treatment of time and place; for example, in the Third Branch, which is a direct sequel to Branwen and also

the raven banner of Ívarr is mentioned in other sources, thought it does not feature in Ragnars saga. See Rowe, Vikings in the West, 48, 88.

72 On Branwen as a postcolonial text, see Patricia Clare Ingham, 'Marking Time: Branwen, Daughter of Llyr and the Colonial Refrain', in The Postcolonial Middle Ages, ed. Jeffrey Jerome Cohen, (Palgrave Macmillan, 2000), 173-91; Catherine McKenna, 'The Colonization of Myth in Branwen Ferch Ly $\hat{r}$ ', in Myth in Celtic literatures, CSANA Yearbook 6, ed. Joseph Nagy (Dublin: Four Courts Press, 2007), 105-119.

73 T. M. Charles-Edwards, Wales and the Britons, 350-1064 (Oxford: Oxford University Press, 2013), 324. 
ostensibly set in pre-Roman Britain, the protagonists of the text anachronistically leave Dyfed, magically transformed into a wasteland by a lord of the otherworld, for Lloegr 'England', to practice various trades before they return to free their kingdom from the enchantment. The unexpected presence of England in Britain several centuries ahead of schedule permits the author to comment on contemporary political concerns within the framework of the legendary past. The references in Branwen to the ruler of Britain having been crowned in London may perform a similar function. They acknowledge the political significance of the city in Norman England, while asserting a much older claim: the Britons ruled from London long before the Normans were Normans.

Likewise, the depiction of England's political geography in Ragnars saga is at odds with the historical record. Ælla is not presented as a regional king ruling over Northumbria, as he appears in other sources, but as the king of all of England, and to say that the saga is vague in its account of English geography would be an extreme undestatement. Ælla’s authority presumably extends over all of the territories historically held by English rulers in the period; in a feat of anachronism breathtaking even by the standards of fornaldarsögur, he grants Ívarr the land on which establishes 'Lundúnaborg', i.e., London: 'Hún er allra borga mest ok ágaæzt of öll Norðrlönd. ${ }^{74}$ As discussed above, Ívarr is elsewhere named as the founder of the city of York in Northumbria. That it is only in Ragnars saga that Ívarr is associated with London is curious, especially in light of the correspondences with Branwen. It is possible that this is modeled on the political situation in England under Knútr in the early eleventh century or the prominence of London under the Anglo-Normans but I would tentatively suggest that the emphasis placed on London and the depiction of England as a single kingdom ruled by one king in the saga may also reflect an awareness of British traditions of the sovereignty of Britain, even if that tradition, as Charles-Edwards argues, was flexible and readily adapted to contemporary political concerns.

British geography is likewise treated rather loosely in Ragnars saga, and this is most evident when it comes to the placement of Ívarr's gravemound. The location is left unspecified. It is strange that such an important detail as the location of the grave would be omitted. The saga states only that Haraldr Sigurðarson came ashore there and was defeated, and that William of Normandy came there and burned Ívarr's body shortly after. This muddies the water even further,

\footnotetext{
74 "It was the greatest and most praised of all the cities of all the Northern lands." Guðni, Ragnars saga, p. 276.
} 
as Haraldr landed on the northeastern coast in Northumbria, and William invaded from the south. It is not impossible that the author of Ragnars saga was simply ignorant of the specifics of the campaigns, but other sagas display a detailed, if not always accurate, knowledge of the two invasions. I suggest that the author is being deliberately vague, in keeping with the fanciful, almost fairy-tale-like, treatment of English geography in Ragnars saga. Compare the account of Haraldr's invasion found in the late-thirteenth century Hemings páttr Áslákssonar. Haraldr's fleet sails from Norway to Orkney, where he leaves his daughter and some of his followers. The fleet sails from Orkney to Skarðarborg (Scarborough), where it is becalmed for the night, and from there south to Kliflọnd 'Cleveland'. Haraldr spies a raised headland, and asks Tósti the name of the landscape feature. Tósti demurs, but Haraldr persists, and Tósti reveals that it is the 'havgr Ivars beinlavsa' (gravemound of Ívarr the boneless). The king replies 'fair hafa peir sigrað England er at hans havgi hafa first komit ${ }^{75}$ (few are those who have conquered England who have come first to his gravemound). Later, the páttr relates that when William invaded, it was said that 'hann let brenna Ivar en beínlavsa aðr hann tok at heria ${ }^{76}$ (he had Ívarr the boneless burned before he began to raid). Hemings páttr has been tentatively dated to the thirteenth century, ${ }^{77}$ and is probably adapting the material found in Ragnars saga; if that is the case, the author has augmented the saga's sparse account with material from other texts. ${ }^{78}$ The description in Hemings páttr very precisely maps out Haraldr's journey. The level of detail is striking, whatever the relationship between the páttr and the saga, and highlights the sparseness of the saga's account in the saga.

It is not clear what Hemings páttr's source for Ívarr's burial is. Rowe calls this scene an 'echo of Ragnars saga', and later states that it 'appears to be derived from the same tradition about Ívarr that is described in ch. 18 of Ragnars saga. ${ }^{79}$ This could represent independent knowledge of traditions about Ívarr's burial circulating in thirteenth-century Iceland, or that the

\footnotetext{
${ }^{75}$ Gillian Fellows Jensen, ed., Hemings páttr Ásláukssonar, Editiones Arnamagnæanæ Series B, vol. 3 (Ejnar Munksgaard: Copenhagen, 1962), 46.

76 Jensen, Hemings páttr, 55.

${ }_{77}^{77}$ Anthony Faulkes, Hemings Páttr (Thorisdal: Dundee, 2016), 6.

${ }^{78}$ Ragnarssona páttr also has Ívarr dying in England (though of old age, as opposed to illness in Ragnars saga) and being buried in a grave-mound: "varð hann ellidavðr a Englandi ok var par heygðr'; however, there is nothing in the páttr that resembles the notion that Ívarr's burial was in way protective. Ragnarssona páttr, 465.

${ }^{79}$ Rowe, Vikings in the West, 239-40.
} 
author of the páttr was familiar with Ragnars saga. Whether this is an example of intertextual borrowing between Icelandic sources, or a tradition becoming attached to Ívarr in Britain and making its way independently into different narratives in Iceland, it does not affect the argument made here, that at some point in Britain legends of the burial of Brân's head to protect the island became transferred to Ívarr beinlausi.

The burial of another Scandinavian ruler has been compared to the burials of Brân and Vortimer, and thus deserves a brief mention here. Patrick Sims-Williams, commenting on the distribution of Gwerthefyr's bones in the ports of Britain in the Trioedd, states that '(t)his variant may be influenced by the type of story represented by Snorri's account in Heimskringla' of the burial of Hálfdan svarti. ${ }^{80}$ Upon the king's death, four districts competed for ownership of his corpse, believing that whichever district possessed his remains would prosper; by way of solution, his body was divided into four portions and distributed among the districts. ${ }^{81}$ SimsWilliams does not speculate on what, if any, connection there might be between the Trioedd and Heimskringla, and it is possible that he is viewing this a circulating folk motif. Bruce Lincoln has argued that Hálfdan's dismemberment and burial is based in part on the myth of Ymir, and while this may well reflect a very old tradition, ${ }^{82}$ the attribution of this type of burial to Hálfdan svarti does not appear in earlier sources, and is probably an innovation of the author of Heimskringla. ${ }^{83}$ I would suggest, then, that what we are seeing in these texts is back-attribution to historical figures of contemporary beliefs about the power of saints' relics and competitiveness over their distribution, and that a similar process has taken place in the depiction of Vortimer's burial in the Trioedd.

In conclusion, there appears to have been a tradition, recorded in post-Conquest AngloLatin texts, that in the aftermath to the Norman Invasion, William of Normandy arranged for the burial of his defeated rival, Harold Godwinson, on the English coast. This is in keeping with the relationship between activities occurring in connection to burial places, including haug-brot and reburial, and the transfer of power between dynasties, as reflected in (later) Icelandic texts and

\footnotetext{
${ }^{80}$ Patrick Sims-Williams, 'The Death of Urien', Cambrian Medieval Celtic Studies 32 (1996): 25-56, at 46.

${ }^{81}$ Bjarni Aðalbjarnarson, ed. Heimskringla I, Íslenzk fornrit, 26 (Reykjavík: Hið íslenzka fornritafélag, 1941), 92-3.

${ }^{82}$ Hermann Güntert, Der Arische Weltkönig und Heiland (Halle: Max Niemeyer, 1923), 326-343. ${ }^{83}$ Bruce Lincoln, Between History and Myth: Stories of Harald Fairhair and the Founding of the State (Chicago: University of Chicago Press, 2014), 72-79.
} 
the archaeological record. The Norman invasion of England and the threat of Anglo-Norman conquest of Wales influenced the development of Welsh accounts of the burial of Brân's head in London, where it guarded against invasion from France until exhumed by King Arthur. I have argued that this tradition became attached to Ívarr inn beinlausi, possibly via cultural connections between Gwynedd and Orkney, and was adapted to Norse conventions. The account of Ívarr's death, burial, and exhumation in Ragnars saga skillfully interweaves Norse, Welsh, and AngloNorman material, a reminder of the sophisticated and multi-cultural milieus in which many of these legendary saga narratives took shape. 